\title{
Chronic autoimmune thyroid disease in children and adolescents in the years 1999-2004 in Lower Silesia, Poland
}

\author{
Teresa Żak ${ }^{1}$, Anna Noczýnska ${ }^{1}$, Renata Wąsikowa ${ }^{1}$, Urszula Zaleska-Dorobisz ${ }^{2}$, \\ Anna Golenko ${ }^{1}$
}

${ }^{1}$ Chair and Clinic of Endocrinology and Diabetology in the Developmental Age, University of Medicine, Wrocław, Poland, ${ }^{2}$ Department of Radiology University of Medicine, Wrocław, Poland

\begin{abstract}
The aim of the study was to analyze data related to chronic autoimmune thyroid disease at diagnosis and at follow-up of children and adolescents in Lower Silesia in the years 1999-2004. Age, gender, incidence of thyroid disease in the family, clinical presentation, hormonal findings, levels of thyroid antibodies, results of ultrasonography, and fine needle aspiration biopsy (FNAB) were recorded. 100 children, 10 boys and 90 girls, were included in the analysis. The mean age at diagnosis was $12.3 \pm 2.3$ years and at last examination $14.9 \pm 1.9$ years. At diagnosis, increased levels of TSH without overt hypothyroidism was observed in 26 children. In 11 children hyperthyroidism was detected whereas 63 children were euthyroid. An increased level of thyroid peroxidase antibodies was observed in $65 \%$ of the children. Ultrasonography was characteristic for Hashimoto's thyroiditis in all patients. Fine needle biopsy was performed when there were diagnostic difficulties (35\% children). Thus, in all the children the diagnosis of Hashimoto's thyroiditis was ascertained either by high antibody titer or FNAB. Associated diseases were observed in $33 \%$ of the children. Thyroid disease in the family was present in $25 \%$ of the children. There was a gradual decline in the number of new cases presented from 1999 to 2004. The reason for this decline remains speculative.
\end{abstract}

Key words: Hashimoto's thyroiditis, Autoimmune thyroid disease, Iodine prophylaxis

\section{INTRODUCTION}

In the past, the most frequent cause of thyroid

Address correspondence and requests for reprints to: Dr Teresa Żak, Department of Endocrinology and Diabetology in the Developmental Age, University of Medicine, Wrońskiego 13c 50-376 Wrocław, Poland, Tel./Fax: +48/71 3280682, e-mail: teresa.zak@post.pl Received 07-09-04, Revised 15-11-04, Accepted 01-12-04 disease in children and adolescents was iodine deficiency. To date, in developed countries, thyroid autoimmunity, either lymphocytic thyroiditis or Grave's disease, constitute the most frequently encountered thyroid pathology. Chronic thyroiditis, also called chronic lymphocytic or autoimmune thyroiditis, was first reported by Hashimoto in $1912^{1}$ and it may be clinically manifested as enlargement or atrophy of the thyroid gland. ${ }^{2}$ The term Hashimoto's 
thyroiditis is still used for the goitrous form of the disease. In about $90 \%$ of patients with Hashimoto's thyroiditis, high levels of antibodies against thyroid peroxidase (anti-TPO) and thyroglobuline (ATg) are detected. Antibodies blocking or stimulating the TSH receptor have been found in about $10 \%$ of the cases (usually in the atrophic form of the disease). Factors which predispose to the development of chronic lymphocytic thyroiditis are genetic and environmental ${ }^{3}$. Among the environmental factors are high iodine consumption, viral infections and drugs. Many authors have observed an increase in the incidence of autoimmune diseases of the thyroid after introduction of iodine prophylaxis in endemic regions..$^{4-7}$ Most likely, environmental factors trigger an autoimmune process in subjects with a genetic predisposition. ${ }^{8-10}$ In Poland, obligatory iodine prophylaxis was introduced in 1997 . In subjects over 18 years a relative increase of the cytologic diagnosis of chronic lympocytic thyroiditis has subsequently been observed. ${ }^{11}$ Contrary to these data, Zimmerman et $\mathrm{al}^{12}$ did not detect induction of thyroid autoimmunity in iodine deficient children in Northern Morocco 1 year after the introduction of iodized salt. It is well known that Hashimoto's thyroiditis is associated not only with other autoimmune diseases, like diabetes type 1, Addison's disease, myasthenia gravis, vitiligo, celiac disease, but also with genetic disorders like trisomy 21 or Turner's syndrome.

The aim of our study was to retrospectively analyze the mode of presentation and the follow-up of autoimmune thyroiditis in children and adolescents diagnosed in Lower Silesia in the years 1999-2004.

\section{SUBJECTS AND METHODS}

The study group included 100 children, 10 boys and 90 girls, who presented at the endocrine out patient department of the endocrine clinic of the University of Medicine Hospital in the years 19992004, and originated from Lower Silesia. The age at presentation was $12.3 \pm 2.3$ years and at last examination $14.9 \pm 1.9$ years. The following data were recorded: physical examination data, serum values of TSH, FT4, FT3, antithyroid antibodies (anti-TPO), as well as results of thyroid ultrasonography and fine needle aspiration biopsy (FNAB). TSH, FT3, FT4 and anti-TPO were determined by immunofluorescence. Normal values were: TSH; 0.4 to $4 \mu \mathrm{U} / \mathrm{ml}$, FT4; 0.8-1.9ng/dl, FT3; 1.5-4.1 pg/ml; anti-TPO 0$35 \mathrm{IU} / \mathrm{ml}$. Ultrasonography was performed by using a high frequency $715 \mathrm{MH} 3$ linear RA transducer.

\section{RESULTS}

The results are presented as means and standard deviation (SD). All patients had normal growth, (Table 1) weight and puberty. Thyroid disease in the family was ascertained in $25 \%$ of the children. Mean age of the children at diagnosis of autoimmune thyroiditis was $12.3 \pm 2.3$ years. At diagnosis, 26 children $(26 \%)$ had increased levels of TSH, without overt clinical hypothyroidism, $11 \%$ had symptoms of mild hyperthyroidism whereas $63 \%$ were euthyroid. In general, the patients were presented with the following signs or symptoms: thyroid enlargement, weakness, tachycardia, decrease or increase of body weight or dry skin. The mean level of TSH in the whole group at diagnosis was $15.18 \pm 41.1 \mathrm{uIU} /$ $\mathrm{ml}$, the mean level of FT4 was $1.78 \mathrm{ng} / \mathrm{dl} \pm 2.84$, the mean level of FT3 was $4.14 \mathrm{pg} / \mathrm{ml} \pm 2.5$. Positive antiTPO were found in $65 \%$ of the cases. The remaining did not have high titer and the diagnosis was made by FNAB. The mean level of antibodies (anti$\mathrm{TPO}$ ) was $622.15 \mathrm{IU} / \mathrm{ml} \pm 579.9$. At last examination (aged 14.9 \pm 1.9 ) mean level of TSH was $1.88 \mathrm{UI} /$ $\mathrm{ml} \pm 1.26$, FT4 $1.66 \mathrm{ng} / \mathrm{dl} \pm 1.58$, FT3 $3.63 \mathrm{pg} /$ $\mathrm{ml} \pm 1.43$, anti-TPO $517.41 \mathrm{IU} / \mathrm{ml} \pm 488$. The hormonal data and those of antithyroid antibodies are shown in Tables 2 and 3, separately for the 3 groups (euthyroid, hypothyroid and hyperthyroid). A characteristic ultrasonographic picture was observed in all patients: hypoechogenicity, with increased blood flow. The echo structure in general was heterogeneous. A fine needle biopsy was performed in $35 \%$ of children and in all of them the diagnosis of Hash-

Table 1. Certain anthropometric data of patients with chronic lympocytic thyroiditis

\begin{tabular}{lccc}
\hline & age (years) & height $(\mathrm{cm})$ & BMI $(\mathrm{kg} / \mathrm{m} 2)$ \\
\hline at diagnosis & & & \\
$\mathrm{n}=100$ & $12.3 \pm 2.3$ & $165 \pm 9.6$ & $20.5 \pm 2.3$ \\
$\begin{array}{l}\text { at last examination } \\
\mathrm{n}=100\end{array}$ & $14.9 \pm 1.9$ & $167 \pm 9.5$ & $20.3 \pm 1.7$ \\
\hline
\end{tabular}


Table 2. Hormonal levels and anti-TPO titer at diagnosis (mean \pm SD)

\begin{tabular}{lcccc}
\hline $\begin{array}{l}\text { Clinical } \\
\text { condition }\end{array}$ & FT3 pg/ml & FT4 ng/dl & TSH mIU/ml & ATPO uIU/ml \\
Euthyroid n:63 & $\mathbf{N ~ 1 , 5 - 4 , 1}$ & $\mathbf{N ~ 0 , 8 - 1 , 9}$ & $\mathbf{N ~ 0 , 4 - 4 , 0}$ & 0-35 \\
Hyperthyroid n:11 & $4,1 \pm 1,1$ & $1,7 \pm 0,9$ & $2,41 \pm 1$ & $135 \pm 53$ \\
Hypothyroid n:26 & $4,9 \pm 1,5$ & $2,9 \pm 1,9$ & $0,25 \pm 0,6$ & $667 \pm 302$ \\
\hline
\end{tabular}

Table 3. Anti-TPO titer and thyroid hormones (mean \pm SD) at follow-up (aged $14.9 \pm 1.9$ years)

\begin{tabular}{lcccc}
\hline Clinical condition at presentation & TSH $(\boldsymbol{\mu I U} / \mathbf{m l})$ & FT4 $(\mathbf{n g} / \mathbf{d l})$ & FT3 $(\mathbf{p g} / \mathbf{n l})$ & anti-TPO $(\mathbf{I U} / \mathbf{m l})$ \\
\hline Hypothyroid & $2,7 \pm 1,5$ & $1,2 \pm 0,5$ & $3,3 \pm 2,3$ & $679 \pm 340$ \\
Hyperthyroid & $1,9 \pm 0,9$ & $1,8 \pm 0,3$ & $3,1 \pm 2,1$ & $452 \pm 353$ \\
Euthyroid & $2,5 \pm 1,7$ & $1,2 \pm 0,5$ & $2,7 \pm 1,7$ & $120 \pm 34$ \\
\hline
\end{tabular}

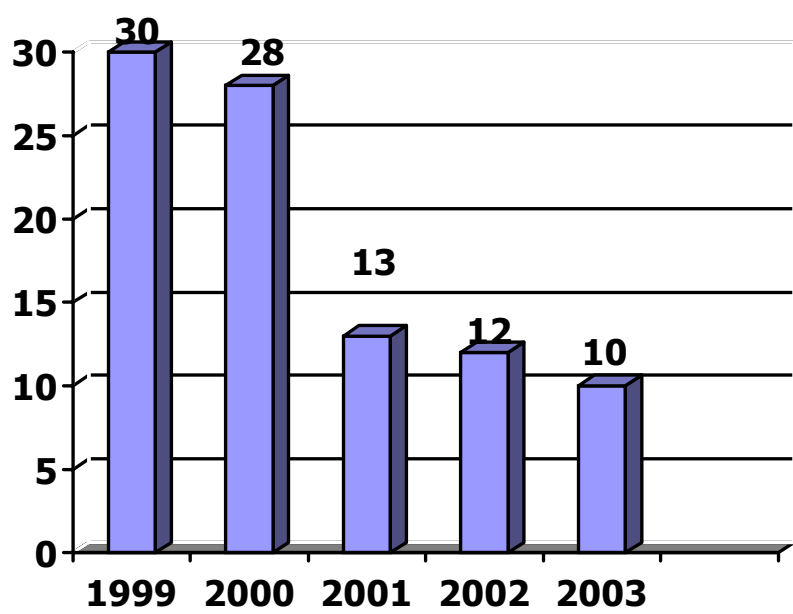

Figure. The number of new cases of chronic autoimmune thyroiditis in the years 1999-2003.

imoto's was made. Malignancy was not detected in any of the cases. Additional diseases were observed in 33 children $(33 \%)$; these were type 1 diabetes mellitus (14\%), PCOS (5\%), Turner syndrome (3\%) and Down syndrome (3\%). Thyroxine therapy was administered in the 26 patients with subclinical hypothyroidism.

\section{DISCUSSION}

Environmental and genetic factors are both involved in the etiology of Hashimoto's thyroiditis (HT). ${ }^{10,13}$ In populations in whom iodine prophylaxis was introduced, an increase of autoimmune diseases of the thyroid was noted. ${ }^{3}$ The obligatory io- dine prophylaxis consisting in iodination of kitchen salt $(30 \pm 10 \mathrm{mg} \mathrm{KI} / \mathrm{kg}$ salt) was introduced in Poland in 1997 and in the year 2002, Poland was accepted by WHO in the group of countries with sufficient iodine supply. The frequency of goiter has decreased in Poland to below $5 \%$ of the population. ${ }^{14}$ The studies performed in certain countries, currently with a good iodine supply, have shown an increase of autoimmune thyroiditis in children. In Greece in a study reported in 1999 it was shown that the predominant form of nontoxic goiter was autoimmune thyroiditis. In Poland, Bobeff and al found that in children from the Lodz macroregion the frequency of chronic thyroiditis increased from $3.7 \%$ in the years $1992-1996$ to $11.2 \%$ in the years $1997-2001 .^{15}$ Zimmerman and al have reported a transient increase in the prevalence of detectable antithyroid antibodies after introduction of iodized salt ${ }^{12}$. In our own study we observed a decrease in the frequency of new cases of chronic lympocytic thyroiditis from 1999 to May 2004 from 30\% in the year 1999 to about $10 \%$ in 2003 . This could be interpreted as a flare-up of HT shortly after the introduction of obligatory iodine prophylaxis and a tapering off subsequently. Alternatively, the decrease may represent a diversion of the patients to other centers. The majority of children were euthyroid (63\%). Subclinical hypothyroidism was ascertained in $26 \%$ of the children, and a hyperthyroid state in $11 \%$. It is of interest that the lowest titer of anti-TPO was detected in the euthyroid group and the highest in the hypothyroid. Hashimoto thyroiditis, as expected, was much 
more frequent in girls, in agreement with other reports in the literature. ${ }^{16,17}$ In children with high TSH, the introduction of thyroxin therapy led to the normalization of TSH, without changes in anti-TPO titer over the 2 years of follow-up. Coexisting diseases were diagnosed in 33 children (33\%), most often diabetes type 1 , which is in agreement with the reports in the literature ${ }^{13,18-22}$. Thyroid diseases in the family were ascertained in $25 \%$ of the children. Segni and $\mathrm{et}^{13}$ found a positive family history in $36 \%$ and Marinovic ${ }^{20}$ in $23 \%$ of examined children.

In summary, in $65 \%$ of children with sonographic evidence of thyroiditis, a high titer of thyroperoxidase antibodies was detected. In the remaining $35 \%$ with low antibody titer, the diagnosis was ascertained by FNAB. The majority of the children (63\%) were euthyroid at presentation (clinically and hormonally), and $11 \%$ were mildly hyperthyroid. There was a decline in the number of new cases of HT from 1999 to 2004, which could be incidental. Alternatively, it could be the result of a transient rise in the years 1999-2000 following obligatory salt iodination in Poland in 1997.

\section{REFERENCES}

1. Hashimoto H, 1912 Zur kenntniss der lymphomat $\varphi$ ser Veränderung der Schildrüse (Struma lymphomatosa). Arch Klein Chir 97: 219-289.

2. Lewiński A, 2004 Managment of Thyroiditis. Adv Clin Exp Med, 13: 87-103.

3. Pearce EN, Farwell AP, Braverman LE, 2003 Thyroiditis. N Engl J Med 348: 2646-2655.

4. Benvenga S, Bartolone L, Squadrito S, Trimarchi F, 1997 Thyroid hormone autoantibodies elicited by diagnostic fine needle biopsy. J Clin Endocrinol Metab 82: 4217-4223.

5. Foley TP, 1992 The relationship between autoimmune thyroid disease and iodine intake. Polish J Endocrinol 43: 53-69.

6. Kahaly G, Dienes HP, Beyer J, Hommel G, 1997 Randomized, double placebo-controlled trial of low dose iodine in endemic goiter. J Clin Endocrinol Metab 82: 4049-4053.

7. Papanastasiou L, Alevizaki M, Piperingos G, Mantzos E, Tseleni-Balafouta S, Koutras DA, 2000 The effect of iodine administration on the development of thyroid autoimmunity in patients with nontoxic goiter. Thyroid 10: 493-497.

8. Tomer Y, 2001 Unraveling the genetic suscepibility to autoimmune thyroid diseases: CTLA-4 takes the stage. Thyroid 11: 167-169.

9. Kristiansen OP, 2000 CTLA-4 in autoimmune diseases-a general susceptibility gene autoimmunity? GenesImmun 1: 170-184.

10. Weetman AP, Mc Gregor AM, 1994 Autoimmune thyroid disease: further developments in our understanding. Endocr Rev 15: 788-830.

11. Słowińska-Klencka D, Klencki M, Sporny S, Lewiński A, 2002 Fine-needle aspiration biopsy of the thyroid in an area of endemic goiter: influence of restored sufficient iodine supplementation on the clinic significance of cytological results. Eur J Endocrinol 146: 1926.

12. Zimmermann MB, Moretti D, Chaouki N, Torresani T, 2003 Introduction of iodized salt to severely iodinedeficient children does not provoke autoimmunity: a one year prospective trial in Northern Morocco. Thyroid 13: 199-203.

13. Segini M, Wood J, Pucarelli I, Toscano V, Toscano R, Pasquino AM, 2001 Clustering of Autoimmune Thyroid Diseases in Children an Adolescents: a Study of 66 Families. J Pediatr Endocrinol Metab 14: 1271-1275.

14. Szybinski Z, 2002 Niedobór jodu a epidemiologia raka tarczycy w Polsce. Polish J Endocrinol 53: 19-21.

15. Bobeff I, Pniewska-Siark B, Zygmunt A, Lewinski A, 2003 Wpływ wprowadzenia obligatoryjnego modelu profilaktyki jodowej na niektóre wskaźniki podaży tego pierwiastka oraz częstość poszczególnych rozpoznan cytologicznych w guzkach tarczycy u dzieci z makroregionu łódzkiego. Endokrynol Ped 2: 29-35.

16. Roth C, Scoreta M, Stubbe P, et al, 1997 Autoimmune thyreoiditis in childhood-epidemiology, clinical and laboratory findings in 61 patients. Exp Clin Endocrinol Diab 105: 66-69.

17. Lewiński A, 1998 Zapalenia tarczycy In: Romer TE (eds) Endokrynologia kliniczna, Warszawa, Springer PWN; pp, 412-416.

18. Szewczyk L, Ben-Skowronek I, 2003 Cukrzyca insulinozależna typu $1 \mathrm{i}$ autoimmunologiczne choroby tarczycy u dzieci. Nowa Pediat 7: 17-19.

19. Muchacka-Bianga M, Deja G, Jarosz-Chobot P, 2000 Zaburzenia funkcji tarczycy u dzieci z cukrzycą typu 1 przewlekle zdekompensowanych Diabetol Pol 7: 104107.

20. Marinovic D, Leger J, Garel C, Czernichow P, 2000 Chronic autoimmune thyroiditis in the childchood. Archiv Pediat 7: 1284-1292.

21. Watemberg N, Willis D, Pelloc JM, 2000 Encephalopathy as the presenting symptom of Hashimoto's thyroiditis. J Child Neurol 15: 66-69.

22. Piontek E, Witkowski D, 2003 Cukrzyca t. 1 u dzieci, a inne choroby o podłożu autoimmunologicznym. Nowa Pediat 7: 48-50. 


\title{
Improved somatic growth following adenoidectomy and tonsillectomy in young children. Possible pathogenetic mechanisms
}

\author{
Harilaos S. Vontetsianos ${ }^{1}$, Spiros E. Dauris ${ }^{1}$, George D. Christopoulos ${ }^{1}$, \\ Catherine Dacou-Voutetakis ${ }^{2}$
}

${ }^{1}$ ENT Department and ${ }^{2}$ Endocrine Unit, First Paediatric Department, Athens University, Children's Hospital "Agia Sophia" Athens, Greece

\begin{abstract}
The effect of Adenotonsillectomy on somatic growth was studied prospectively in 57, randomly selected children ( 31 boys, 26 girls), aged 5.03 \pm 1.32 (mean $\pm 1 S D$ ) years. The indication for surgery was adenotonsillar hypertrophy with or without recurrent infections. Weight, height, triceps skinfold thickness, and Body Mass Index were measured prior to the operation and 613 months afterwards. Weight was significantly improved following $T \& A$ in all children. The improvement in height was significant only for children under 5 years. In an attempt to uncover the pathogenetic mechanisms, lactic acid, pyruvic acid, somatomedin-C (IGF-I), growth hormone (GH), insulin, glucose, $\mathrm{pH}$, hemoglobin (Hß), and white cell count (WBC) were also determined in the last 18 children, prior to and 6-8 months post operatively. For the comparison of pre and post operative values the paired t test was applied. Although the values of GH and IGF1 did not significantly increase post-op the IGF-1/GH ratio increased, possibly indicating improved IGF1 generation. There was also a rise in $\mathrm{H \beta}$ values and a lowering of $\mathrm{WBC}$, probably reflecting the lower frequency of infections. All other metabolic indices did not change. In conclusion, linear grow post-Adenotonsillectomy improved in children aged $<5$ years and was associated with improved IGF-1/GH ratio, increased $\mathrm{H \beta}$ values and decreased in WBC.
\end{abstract}

Keywords: Growth retardation, Adenotonsillectomy, Growth hormone, IGF1

\section{INTRODUCTION}

The major indications for adenotonsillectomy (T\&A) have remained the same for many years and

Address correspondence and requests for reprints to:

C. Dacou-Voutetakis, V. Ipirou 4, Papagos, 15669 ,

Professor of Pediatric Endocrinology, Athens University, Head Endocrine Unit

Received 07-09-04, Revised 12-11-04, Accepted 25-11-04 include, recurrent pharyngotonsillitis and its complications, excisional biopsy, management of chronic ear disease, and chronic upper respiratory obstruction. ${ }^{1-5}$ Currently, the most frequent indication for T\&A is upper airway obstruction due to hypertrophy of the tonsils and adenoids. ${ }^{5}$ Chronic upper airway obstruction can lead to obstructive sleep apnea syndrome (OSAS) with chronic alveolar hypoventilation, cor pulmonale, cardiac failure ${ }^{6-15}$ sleep disor- 
ders, ${ }^{16-19}$ behavioral changes, learning disability, enuresis, and retarded growth., ${ }^{1,8,14,20-23}$ Published data on the influence of T\&A on somatic growth refer to case reports, ${ }^{24-27}$ or include small number of patients, ${ }^{6-8,28}$ younger than 3 years, primarily affected by OSAS. In these studies, most of the children were underweighted pre-operatively (pre-op), and presented "catch-up" growth after T\&A. Other trials ${ }^{29,23}$ looked retrospectively to the improvement of somatic growth. A small number of prospective studies, have been published in which, OSAS was mainly correlated to changes in growth post-op. Results concerning the influence of recurrent tonsillitis on somatic growth are controversial. ${ }^{20,30,31}$ There are reports $^{28,8}$ which show that only tonsillectomy had a positive influence on somatic growth post-operatively (post-op), while others found that adenoidectomy is as effective as tonsillectomy or T\&A. The pathogenetic mechanism involved have not been elucidated. In the present study the influence of T\&A on height and weight was studied prospectively in children aged $5.03 \pm 1.32$ years, who were operated upon for various indications. An attempt was also made to look into pathogenetic mechanism responsible for the alteration in growth pattern, following T\&A.

\section{PATIENT SELECTION AND METHODS}

Fifty seven children, 31 boys $(54.3 \%)$ and 26 girls $(45.6 \%)$ were studied. The age of the patients at entrance to the study was $5.03 \pm 1.32$ years. The children were randomly selected from the Ear-NoseThroat clinic. The selection criteria were: substantial evidence to justify $T \& A$, absence of any other concurrent disease that may affect growth and informed concent from the parents who accepted to participate in the study and the follow-up visits. Indications for T\&A were: Adenotonsillar hypertrophy with or without recurrent infections. Five tonsillectomies (T), $21 \mathrm{~T} \& \mathrm{~A}$, and 31 adenoidectomies (A) were performed. Nineteen of the children experienced ear problems such as: recurrent acute otitis media, or otitis media with effusion. For these children myringotomy with or without ventilation tube insertion, was also performed.

The weight, height, and triceps skinfold thickness were measured the day prior to surgery, between 9$10 \mathrm{am}$ and the body mass index was estimated using the formula: weight $(\mathrm{kg}) /$ height $(\mathrm{m}) .^{2}$ The measurements were carried out by the same person, following an identical procedure, i.e. the children were weighted in their indoor clothing and without shoes, using a stable balance. The height was measured as length up to the age of five years (lying down) and as height (upright position) past the age of $5 \mathrm{yrs}$, using the Harpenden stadiometer. The triceps skinfold thickness was measured using the Holtain skinfold caliper. Six to thirteen months after operation, the children were once again measured following the same protocol. For the statistical analysis the paired $t$ test was applied. For the auxologic data the standardized weight and height (z scores) and their percentiles were used while for the other parameters the actual values were used.

In the last 18 children of this series the following parameters were additionally determined: lactic acid (Monotest Boehringer), pyruvic acid (Combination test Boehringer), somatomedin-C/IGF-I (Radioimmunoassay-RIA, Nichol's reagents), growth hormone (RIA), glucose (glucose oxidase), insulin (RIA), $\mathrm{pH}$ (venous blood), haemoglobin ( $\mathrm{Hb})$, and white cell count (WCC) by routine methodology, prior to the operation and 6-8 months post operatively.

Parents were asked to report on changes in the activity, the appetite and frequency of infection of their children following the operation.

\section{RESULTS}

\section{Weight (Table I)}

The weight standardized value (z score) for the total group significantly increased following the operation (pre-op value $0.2481 \pm 1.26$, post-op value $0.8793 \pm 1.43, \mathrm{p}=0.0001)$ and the mean percentile value also increased form the $54^{\text {th }}$ percentile, to the $68^{\text {th }}(p=0.0001)$. No difference was observed in these changes between boys and girls.

There was also no difference in the changes observed whether the pre-op weight was above or below the $50^{\text {th }}$ percentile. 
Table I. Pre, and post-op mean values for body Weight expressed in $\mathrm{Z}$ scores and percentiles

\begin{tabular}{lcccc}
\hline All children & $\mathbf{n}$ & Pre-op & Post-op & $\mathbf{p}$ \\
\hline Percentile & 57 & 54.3 & 67.9 & 0.0001 \\
z score & 57 & 0.2481 & 0.8793 & 0.0001 \\
\hline Boys & $\mathbf{n}$ & Pre-op & Post-op & $\mathbf{p}$ \\
\hline Percentile & 31 & 51.1 & 67.2 & 0.0001 \\
z score & 31 & 0.079 & 0.7511 & 0.0002 \\
\hline Girls & $\mathbf{n}$ & Pre-op & Post-op & $\mathbf{p}$ \\
\hline Percentile & 26 & 58.3 & 68 & 0.0005 \\
z score & 26 & 0.4488 & 1.032 & 0.0001 \\
\hline
\end{tabular}

The changes observed according to the type of operation were as follows: Significant increase for those who underwent T\&A and $A(p<0.001$ for both), but not, for those who underwent $\mathrm{T}(\mathrm{p}>0.1)$. In the latter group however, the sample was small (5 children).

\section{Height (Table II)}

The height standardized value (z score) for the total group was significantly increased post-op (preop value $0.4994 \pm 0.9$, post-op value $0.6578 \pm 1.01$, $\mathrm{p}=0.0002)$ and the mean percentile also increased from the $65^{\text {th }}$ to the $69,6^{\text {th }}$ percentile $(\mathrm{p}=0.0001)$. This difference emerged from the children under the age

Table II. Pre, and post-op mean values for Height expressed as z scores and percentiles

\begin{tabular}{lcccc}
\hline All children & n & Pre-op & Post-op & p \\
\hline Percentile & 57 & 65.1 & 69.6 & 0.0001 \\
z score & 57 & 0.4994 & 0.6578 & 0.0002 \\
\hline Boys & $\mathbf{n}$ & Pre-op & Post-op & $\mathbf{p}$ \\
\hline Percentile & 31 & 59.1 & 65.2 & 0.0008 \\
z score & 31 & 0.2379 & 0.44 & 0.0022 \\
\hline Girls & $\mathbf{n}$ & Pre-op & Post-op & $\mathbf{p}$ \\
\hline Percentile & 26 & 72.3 & 74.9 & 0.058 \\
z score & 26 & 0.8111 & 0.9173 & 0.0462 \\
\hline Children under five years & $\mathbf{n}$ & Pre-op & Post-op & $\mathbf{p}$ \\
\hline Percentile & 29 & 64.2 & 71.1 & 0.0002 \\
z score & 29 & 0.408 & 0.6667 & 0.0003 \\
\hline Children over five years & $\mathbf{n}$ & Pre-op & Post-op & $\mathbf{p}$ \\
\hline Percentile & 28 & 66.1 & 68.2 & 0.133 \\
z score & 28 & 0.5941 & 0.6485 & 0.2019 \\
\hline
\end{tabular}

of five, while for the group of children over five (28 children), no significant changes in either standardized value, or percentile were observed $(p=0.2019$, 0.133 respectively). Boys grew somewhat better than girls (Table II).

There was no difference in the changes observed whether the pre-op height was above or below the $50^{\text {th }}$ percentile.

The changes observed according to the type of operation were as for the weight: Significant increase for those who underwent T\&A and $\mathrm{A}(\mathrm{p}<0.001$ for both), but not, for those who underwent $T$ only $(p>0.1)$. In the latter however, as we mentioned before, the sample was small (5 children).

\section{Skinfold thickness (SFT)}

The SFT also increased significantly post-op (mean pre-op and post-op values $10.6 \pm 3.3 \mathrm{~mm}$ and $11.4 \pm 3.7 \mathrm{~mm}$, respectively $\mathrm{p}<0.01)$.

Body Mass Index (BMI) values increased from a pre-op value of $15.85 \pm 1.7$ to $16.7 \pm 2.1$ post-op $(\mathrm{p}<0.001)$.

\section{Hormonal and other hematologic parameters}

Concerning the search for pathogenetic mechanisms the following changes between pre-op and post-op values were observed (Table III): IGF-I form $0.69 \pm 0.31$ to $0.91 \pm 0.71$, growth hormone form $4.1 \pm 4.5$ to $2.1 \pm 3.7$, lactic acid from $17.69 \pm 5.04$ to $20.07 \pm 7.14$, pyruvic acid from $0.37 \pm 0.18$ to

Table III. Pre, and post-op mean values for the hormonal and other hematological parameters

\begin{tabular}{lcccc}
\hline Parameter & $\mathbf{n}$ & Pre-op & Post-op & p \\
\hline IGF-I $(\mathrm{IU} / \mathrm{L})$ & 18 & $0.69 \pm 0.3$ & $0.91 \pm 0.7$ & $>0.1$ \\
G.H. $(\mathrm{mg} / \mathrm{ml})$ & 18 & $4.1 \pm 4.5$ & $2.1 \pm 3.7$ & $>0.1$ \\
IGF1/GH & 18 & $0.56 \pm 0.54$ & $1.38 \pm 1.53$ & $\mathrm{P}<0.025$ \\
Lactic acid $(\mathrm{mg} / \mathrm{dl})$ & 17 & $17.6 \pm 5$ & $20.0 \pm 5$ & $>0.1$ \\
Pyruvic acid $(\mathrm{m} / \mathrm{dl})$ & 17 & $0.37 \pm 0.18$ & $0.38 \pm 0.2$ & $>0.1$ \\
Glucose $(\mathrm{mg} / \mathrm{dl})$ & 18 & $91.2 \pm 1.5$ & $98.7 \pm 17$ & $>0.1$ \\
Insulin $(\mu \mathrm{U} / \mathrm{mg})$ & 18 & $14.6 \pm 12.7$ & $18.3 \pm 15.3$ & $>0.1$ \\
pH $(\mathrm{venous})$ & 16 & 7.33 & 7.33 & $>0.1$ \\
Hb $(\mathrm{gr} / \mathrm{dl})$ & 18 & $12.2 \pm 0.8$ & $12.6 \pm 0.95$ & 0.037 \\
White cell count & 18 & 11558 & 9036 & 0.005 \\
\hline
\end{tabular}


$0.38 \pm 0.2$, glucose from $91.2 \pm 15.6$ to $98.7 \pm 17.1$, insulin from $14.6 \pm 12.7$ to $18.3 \pm 15.03$ and $\mathrm{pH}$ didn't change (7.33). The above changes were not statistically significant. The ratio IGF1/GH increased from a pre-op value of $0.56 \pm 0.54$ to $1.38 \pm 1.53$ post-op $(\mathrm{p}<0.025)$.

A significant difference was found between preop and post-op values of hemoglobin (pre-op $12.2 \pm 0.87$ and post-op 12.6 $\pm 0.95, \mathrm{p}=0.037)$ and white cell count (WBC) $(11558.3 \pm 3295.5$ pre-op, and $9036.6 \pm 2812.3$ post-op, $\mathrm{p}=0.005)$.

According to the parent's opinion the majority of the children had a better appetite and activity 613 months after the operation and, reportedly, less frequent infections post-op.

\section{DISCUSSION}

In this prospective study, somatic growth, as reflected in height, weight, BMI and skinfold thickness, were significantly increased after $T \& A$ in the total group. The improvement in height (z score) was highly significant only in children under five years, irrespective of the indication for surgery, and the pre-op $\mathrm{z}$ score. The underlying mechanisms for this improvement are not known. In the present study, parameters related to impaired oxygenation (lactic acid), growth (IGF1, GH) and infection (H $\beta$ and WBC) were evaluated in an attempt to clarify the pathogenetic mechanisms involved.

Growth hormone $(\mathrm{GH})$ is released in pulsatile fashion during a 24 hours period, mainly during sleep ${ }^{32}$ but the highest $\mathrm{GH}^{33}$ values are associated with the onset of slow wave sleep (SWS). It has been shown that sleep disturbances and specifically a decrease in the amount of SWS occur in children with adenotonsillar hypertrophy. This effect is expected to decrease sleep associated GH secretion. The effect of $\mathrm{GH}$ on skeletal growth appear to be mediated through the somatomedins. The somatomedins or IGF factors are a family of insulin like peptide growth factors modulated by insulin and nutrition as well as by GH. Deficient growth in the presence of adequate $\mathrm{GH}$ secretion could occur because of decreased somatomedin generetion, increased somatomedin inhibitors, or changes in the responsive- ness of the target organ. In children who do not have $\mathrm{GH}$ deficiency, the presence of low somatomedin levels would suggest nutritional insufficiency, chronic illness or genetically impaired IGF1 generation. ${ }^{34}$

Based on the above data we measured values of GH, IGF-1 and other parameters, possibly related to impaired growth. The values of GH IGF1, insulin and glucose did not statistically change post-op, whereas the IGF1/GH ratio significantly increased. With regard to $\mathrm{GH}$, only single values in the morning were measured. A 24-hour integrated concentration of $\mathrm{GH}$ or provocative testing would have been more informative than basal values ${ }^{33,35}$ since it is quite possible that $\mathrm{GH}$ secretion pattern during sleep could be decreased pre-op. For obvious reasons, however, such an experimental design could not be materialized.

Other investigators have also attempted to interpret the increase in growth post $\mathrm{T} \& \mathrm{~A}$. Thus, Marcus et $\mathrm{al}^{36}$ attributed the growth improvement post T\&A to the lowering of energy expenditure which they observed, during sleep, post-op.

Bar et $\mathrm{al}^{37}$ found that IGF1 values but not IGFBP3 increased post T\&A in association with prolongation of slow wave sleep period. They infer that $\mathrm{GH}$ was increased post-op, but actual values of $\mathrm{GH}$ were not determined.

In another study, higher values of IGF1 and IGFBP3 were found.$^{38}$ Based on these findings, the authors speculated that the $\mathrm{GH}$ values had improved. Two other studies also found higher IGF1 and IGFBP3 values post T\&A..$^{39,40}$

In our study, besides IGF1, GH values were also determined in 18 subjects, under basal conditions. Contrary to expectations, the basal GH values tended to be higher pre-op although not statistically significant. As mentioned previously, basal GH values do not adequately reflect sleep associated or 24 hour $\mathrm{GH}$ secretion. Nevertheless, the data are not in favor of lower GH values pre-op. It is quite interesting and provocative that the IGF1 to $\mathrm{GH}$ ratio was higher post-op suggesting an improvement in IGF1 generation by GH. This phenomenon is not unexpected, as it may be encountered in other situations of growth inhibition in which inflammatory respons- 
es predominate. In such cases, GH may be normal, whereas IGF1 levels are low. ${ }^{41}$ Supporting evidence for such a phenomenon is derived from the information that infections were less frequent, the $\mathrm{H} \beta$ values were higher and the WBC was lower post T\&A. Moreover, in another study IL-1beta and IL6 values were significantly lower post $T \& A .{ }^{42} \mathrm{An}$ increase in $\mathrm{H} \beta$ values post $\mathrm{T} \& \mathrm{~A}$ was also detected by Elverland et al. ${ }^{43}$

In conclusion, body weight improved in all children post-op. Height was improved only in children under the age of five. For the latter observation two explanations can be offered. The "catch-up" growth in children over five had already occurred, because the organism itself managed to overcome the pathological condition (escape phenomenon) or "catchup" growth is not possible if the abnoxious factors are not removed early in life. Growth was improved post-op, irrespective of the pre-op percentile for weight and height. Gender was not an important factor. A significant difference in the IGF1/GH ratio was detected post-op possibly indicating improved IGF1 generation. Among the possible pathogenetic mechanisms involved, as emerged from our study, was an impairement in IGF1 generation possibly as a result of better nutrition and or decrease in the frequency of infections.

\section{REFERENCES}

1. Eliaschar I, Lavie P, Harperin E, Gordon C, Alroy G, 1980 Sleep apnea episode as indications for adenotonsillectomy. Arch Otolaryngol 106: 492-496.

2. Grundfast KM, Wittich DJ, 1982 Adenotonsillar hypertrophy and upper airway obstruction in evolutionary perspective. Laryngoscope 92: 650-56.

3. Konno A, Hoshino T, Togawa K, 1980 Influence of upper airway obstruction by enlarged tonsills and adenoids uppon recurrent infection of the lower airway in childhood. Laryngoscope 90: 1709-1716.

4. Potsic WP, 1990 Tonsillectomy and adenoidectomy. An update plus sleep apnea. Common Problems in Pediatric Otolaryngology 297-301.

5. Darrow DH, Siemens C, 2002 Indications for tonsillectomy and adenoidectomy. Laryngoscope 112: 6-10.

6. Brouillete RT, Fernbach SK, Hunt CE, 1982 Obstructive sleep apnea in infants and children. The Journal of Pediatrics 100: 31-40.

7. Guilleminault C, Eldridge FL, Simmons FB, Demert WC, 1976 Sleep apnea in eight children. Pediatrics 58:
23-30.

8. Lind MG, Lundell Bo PW, 1982 Tonillar hyperplasia in children. A cause of obstructive sleep apneas. $\mathrm{CO}_{2}$ retention, and retarded growth. Arch Otolaryngol 108: 650-654.

9. Mangat D, Orr WC, Smith RO, 1977 Sleep apnea, hypersomnolence and upper airway obstruction secondary to adenotonsillar enlargement. Arch Otolaryngol 103: 383-386.

10. Potsic WP, 1989 Sleep apnea in children. The Otolaryngologic Clinics of North America - Ped Otolar 22: 537544.

11. Reilly JS, 1988 Tonsillar and adenoid airway obstruction. Modes of treatment in children. International Anesthesiology Clinics 26: 54-57.

12. Singer LP, Saenger P, 1990 Complications of pediatric obstructive sleep apnea. Otolaryngologic Clinics of North America 23: 665-676.

13. Stool SE, Eavey RD, Stein NL, Sharrah WG, 1977 The "Ghubby Puffer" Syndrome. Clinical Pediatrics 16: 4350.

14. Sukerman S, Healy GB, 1979 Sleep apnea syndrome associated with upper airway obstruction. Laryngoscope 89: 878-885.

15. Yonkers AJ, Spaur RC, 1987 Upper airway obstruction and the pharyngeal lymphoid tissue. Otolaryngologic Clinics of North America 20: 235-239.

16. Mandel EM, Reynolds III CE, 1981 Sleep disorders associated with upper airway obstruction in children. Pediatric Clinics of North America 28: 897-903.

17. Mark JD, Brooks JG, 1984 Sleep associated airway problems in children. Pediatric Clinics of North America 31: 907-918.

18. Potsic WP, Wetmore RF, 1990 Sleep disorders and airway obstruction in children. The Otolaryngologic Clinics of North America 23: 651-663.

19. Stradling JR, Thomas G, Warley ARH, Williams P, Freeland A, 1990 Effect of adenotonsillectomy on nocturnal hypozaemia, sleep disturbance, and symptoms in snoring children. The Lancet 335: 294-53.

20. Barr GS, Osborne J, 1988 Weight gain in children following tonsillectomy. The Journal of Laryngology and Otology 102: 595-597.

21. Bate TWP, Price DA, Holme CA, Mc Gucken RB, 1984 Short stature caused by obstructive apnea during sleep. Arch Dis Child 59: 78-80.

22. Hodges S, Wailoo MP, 1987 Tonsillar enlargement and failure to thrive. British Medical Journal 295: 541-542.

23. Williams EF $3^{\text {rd }}$, Woo P, Miller R, Kellman RM, 1991 The effects of adenotonsillectomy on growth in young children. Otolaryngol Head \& Neck Surg 104: 509-516.

24. Van Someren VH, Hibber J, Stothers JK, Kyme MC, Morrison GAJ, 1989 Indentifying hypoxaemia in children admitted for adenotonsillectomy. Br Med J 298: 1076.

25. Everett AD, Koch WC, Saulsbury FT, 1987 Failure to 
thrive due to obstructive sleep apnea. Clinical Pediatrics 26: 90-92.

26. Sciffmann R, Faber J, Eidelman AI, 1985 Obstructive hypertrophic adenoids and tonsils as a cause of infatile failure to thrive: reversed by tonsillectomy and adenoidectomy. Int J Pediatr Otorhinolaryngol 9: 183-187.

27. Shaw NJ, Bowler I, Dear PRF, 1987 Tonsillar enlargement and failure to thrive. British Medical Journal 295: 1065.

28. Leiberman A, Tal A, Brama I, Sofer S, 1988 Obstructive sleep apnea in young infants. Int $\mathrm{J}$ Pediatr Otorhinolaryngol 16: 39-44.

29. Berkowitz RG, Zalzal GH, 1990 Tonsillectomy in children under 3 years of age. Arch Otolaryngol Head Neck Surg 116: 685-686.

30. Grace A, Veitch D, Ryan R, Barnes N, Coles T, 1988 Recurrent tonsillitis and growth in children. Int $\mathrm{J}$ Pediatr Otorhinolaryngol 16: 91-93.

31. Mills RP, Hibbert J, 1983 The effects of recurrent tonsillitis on growth and cervical lymphadenopathy in children. Int J Pediatr Otorhinolaryngol 6: 77-82.

32. Finkelstein JW, Roffwarg HP, Boyar RM, Kream J, Hellman L, 1972 Age-related change in the twentyfour-hour spontaneous secretion of growth hormone. J Clin Endocrinol Metab 35: 665-670.

33. Underwood LE, Azumi K, Voina SJ, Van Wyk JJ, 1971 Growth hormone levels during sleep in normal and growth hormone deficient children. Pediatrics 48: 946954.

34. Phillips LS, Unterman TG, 1984 Somatomedin activity in disorders of nutrition and metabolism. Clin Endocrinol Metab 13: 145-189.

35. Zadic Z, Chalew SA, Raiti S, Kowarski AA, 1985 Do short children secret insufficient growth hormone?
Pediatrics 76: 355-360.

36. Marcus CL, Carroll JL, Koerner CB, Hamer A, Lutz J, Loughlin GM, 1994 Determinants of growth in children with the obstructive sleep apnea syndrome. J Pediatr 125: 556-562.

37. Bar A, Tarasiuk A, Segev Y, Phillip M, Tal A, 1999 The effect of adenotonsillectomy on serum insulin-like growth factor-I and growth in children with obstructive sleep apnea syndrome. J Pediatr 135: 76-80.

38. Selimoglu E, Selimoglu MA, Orbak Z, 2003 Does adenotonsillectomy improve growth in children with obstructive adenotonsillar hypertrophy? J Int Med Res 31: 84-87.

39. Yilmaz MD, Hosal AS, Oguz H, Yordam N, Kaya S, 2002 The effects of tonsillectomy and adenoidectomy on serum IGF-I and IGFBP3 levels in children. Laryngoscope 112: 922-925.

40. Nieminen P, Lopponen T, Tolonen U, Lanning P, Knip M, Lopponen H, 2002 Growth and biochemical markers of growth in children with snoring and obstructive sleep apnea. Pediatrics 109: 55.

41. Tsatsoulis A, Siamopoulou A, Petsoukis C, Challa A, Bairaktari E, Seferiadis K, 1999 Study of growth hormone secretion and action in growth retarded children with juvenile chronic arthritis (JCA). Growth Horm IGF Res 9: 143-149.

42. Unal M, Ozturk C, Gorur K, 2002 Effect of tonsillectomy on serum concentrations of interleukins and TNF-alpha in patients with chronic tonsillitis. ORL J Otorhinolaryngol Relat Spec 64: 254-256.

43. Elverland HH, Aasand G, Miljeteig H, Ulvik RJ, 2004 Effects on tonsillectomy and adenoidectomy on hemoglobin and iron metabolism. Int J Pediatr Otorhinolaryngol 68: 419-423. 